\title{
Design thinking w zarządzaniu projektami - ocena możliwości zastosowania
}

\author{
Dr hab. Ewa Sońta-Drączkowska \\ Szkoła Główna Handlowa w Warszawie, Instytut Zarządzania \\ Katedra Zarządzania Projektami
}

\section{Wprowadzenie}

W ostatnich latach w zarządzaniu projektami rysuje się dążenie do angażowania klienta i użytkownika już na wczesnym etapie inicjowania projektu. Trend ten współgra z innymi zjawiskami w zarządzaniu. W dzisiejszej gospodarce przedsiębiorstwa stają się w coraz większym stopniu klientocentryczne, a klient nie jest już biernym konsumentem, ale często prosumentem, który aktywnie współtworzy nowe produktu i rozwiązania1. W literaturze dyskusje dotyczące angażowania użytkownika toczą się w nurcie tzw. rozproszonego miejsca powstawiania innowacji (fuzzy-front end of innovation), jak również strategii otwartych innowacji ${ }^{2}$. Dążenia do włączania klienta w proces rozwoju mają znaczenie przede wszystkim na początkowym etapie projektów, w momencie poszukiwania pomysłów na rozwój oraz diagnozy potrzeb organizacji. Etap ten może znacznie wyprzedzać formalne ustanowienie projektu. Szczególne znaczenie współtworzenia z użytkownikiem dotyczy projektów o charakterze eksploracyjnym, na przykład badawczo-rozwojowych, rozwoju nowych produktów i usług, tworzenia młodych spółek technologicznych lub projektów zorientowanych na poprawę doświadczeń klienta z marką. Badania potwierdzają konieczność bliskiej współpracy z klientem w całym cyklu pracy nad przedsięwzięciem innowacyjnym ${ }^{3}$.

1 G. Ritzer, N. Jurgenson, Production, consumption, prosumption: The nature of capitalism in the age of the digital 'prosumer', ,Journal of Consumer Culture” 2010, vol. 10(1), s. 13-36; T. Saebi, N.J. Foss, Business models for open innovation: Matching heterogeneous open innovation strategies with business model dimensions, „European Management Journal” 2015, vol. 33(3), s. 201-213.

2 P. Koen i wsp., Providing clarity and a common language to the "fuzzy front end”, „Research-Technology Management" 2001, vol. 44(2), s. 46-55.

3 Między innymi: R. Maniak, C. Midler, Shifting from co-development to co-innovation, „International Journal of Automotive Technology and Management” 2008, vol. 8(4), s. 449-468; 
W tym kontekście narzędzia i techniki wywodzące się z szerokiego nurtu związanego z projektowaniem i wzornictwem przemysłowym (design), a szeroko ujmując teorią designu, mogą mieć ciekawe zastosowanie w procesie odkrywania potrzeb klienta, poprawy doświadczeń z produktem lub usługą oraz inicjowania i definiowania nowych projektów. Celem niniejszego artykułu jest ocena możliwości zastosowania podejścia design thinking w zarządzaniu projektami, a także określenie kierunków dalszych badań. Badanie ma charakter narracyjny i wykorzystuje przegląd literatury przedmiotu, jak również przegląd metody design thinking w wersji opracowanej przez Hasso Plattner Institute ${ }^{4}$. W szczególności poszukuje się odpowiedzi na następujące pytanie badawcze: „Jakie są możliwości i ograniczenia wykorzystania metody design thinking w projektach o charakterze eksploracyjnym?".

\section{Projekty eksploracyjne}

W ostatniej dekadzie w zarządzaniu projektami rozwinął się nurt badań nad projektami eksploracyjnymi ${ }^{5}$. Projekt eksploracyjny charakteryzuje się wysokim poziomem niepewności. Dotyczy ona zarówno otoczenia jego realizacji, na przykład dostosowania produktu prac do potrzeb i oczekiwań klienta i rynku (product-market fit), jak i ograniczonych możliwości zdefiniowania parametrów zarządzania projektem (zakres, budżet, czas) na wstępie projektu. Projekty te nie mają precyzyjnie określonego celu, szczegółowo opisanych pakietów prac i planu zarządzania ryzykiem ${ }^{6}$. Często ukierunkowane są na odkrywanie problemów lub tworzenie produktów, na które nie istnieje jeszcze rynek ${ }^{7}$. W przypadku tego typu projektów ograniczone zastosowanie mają tradycyjne, deterministyczne metody i techniki planowania projektów. W literaturze można znaleźć wiele badań kwestionujących zasadność zastosowania etapowych, normatywnych technik zarządzania

Ch. Midler, P. Silberzahn, Creating Products in the Absence of Markets: A Robust Design Approach, „Journal of Manufacturing Technology Management” 2008, vol. 19(3), s. 407-420.

4 An Introduction to Design Thinking Process Guide, Hasso Plattner Institute of Design, Stanford 2010.

5 Między innymi: S. Lenfle, Floating in space? On the strangeness of exploratory projects, „Project Management Journal" 2016, vol. 47(2), s. 47-61; S. Lenfle, C. Loch, Lost roots: How project management came to emphasize control over flexibility and novelty, "California Management Review" 2010, vol. 53(1), s. 32-55; S. Lenfle, Toward a genealogy of project management: Sidewinder and the management of exploratory projects, „International Journal of Project Management" 2014, vol. 32(6), s. 921-931.

6 S. Lenfle, Floating in space?...

7 Ch. Midler, P. Silberzahn, Creating Products... 
projektami do pracy z innowacjami i projektami o charakterze eksploracji ${ }^{8}$. Dla zrozumienia logiki pracy z innowacjami niektórzy autorzy proponują porzucić: „[...] the traditional view of the firm as a rational, machine-like entity by drawing on the social and creative character of businesses revealed in design thinking" 9 Niniejszy artykuł nawiązuje do istniejących badań w obszarze projektów eksploracyjnych, jak również do badań na temat zastosowania podejścia design thinking w zarządzaniu projektami i na tej postawie dokonuje krytycznej analizy szans i ograniczeń stosowania tej metody w praktyce gospodarczej.

\section{Design thinking}

Design thinking przeżywa w ostatnich dekadach prawdziwy renesans, a zastosowanie metody wykracza poza poziom projektu i pojawia się w dyskusjach w obszarze zarządzania strategicznego ${ }^{10}$. Samo pojęcie wywodzi się z wielowątkowej i rozwijającej się na przestrzeni ostatniego stulecia teorii designu, która ma korzenie w architekturze i wzornictwie przemysłowym. Dla niektórych badaczy design wymyka się jednoznacznej definicji i jest obecnie zjawiskiem kulturowym, które przeniknęło do wielu dziedzin życia, w tym do nauk o zarządzaniu ${ }^{11}$. Idea designu bazuje na założeniu partycypacji i zaangażowania w działania na rzecz wspólnoty, a korzenie tego myślenia sięgają Platona - greckiego filozofa z IV wieku p.n.e., który rozwiązując dręczące go problemy, często szukał porady u swoich uczniów oraz przedstawicieli różnych grup społecznych. Intensywny rozwój metod partycypacyjnych nastąpił w latach sześćdziesiątych XX wieku wraz z pojawieniem się tzw. szkoły skandynawskiej, która zakładała zaangażowanie użytkownika w fazę rozwoju i prototypowania rozwiązań. W kolejnych dekadach design nabrał konotacji technologicznych, gdyż stosowany był często w projektach rozwoju nowych produktów bazujących na technologiach. W latach osiemdziesiątych ubiegłego wieku podejście angażujące stało się synonimem dla rozwijającego się obszaru projektowania interakcji użytkownika z maszyną (interaction design). Wiele technik stosowanych w ramach podejścia design thinking zostało zaczerpniętych $\mathrm{z}$ nauki, na przykład: badania, testowanie użyteczności, praca z makietami i prototypami.

8 Między innymi: A. Shenhar, D. Dvir, Reinventing project management, Harvard Business School Press, Boston 2007; P. Nightingale, T. Brady, Projects, paradigms and predictability, [w:] G. Cattani i wsp. (red.), Project-based organizing and strategic management, Emerald Group Publishing, Bingley 2011, s. 83-112.

9 M. Hobday, A. Boddington, A. Grantham, An innovation perspective on design: Part 2, „Design Issues" 2012, vol. 28(1), s. 18.

10 A. Ignatius, Design as strategy, „Harvard Business Review” 2015, no. 12.

11 R. Buchanan, Wicked problems in design thinking, „Design Issues” 1992, vol. 8(2), s. 5-21. 
Istotną postacią, która wniosła znaczący wkład w rozwój projektowania skoncentrowanego na użytkowniku (user centered design), był amerykański badacz Donald Norman ${ }^{12}$. W ramach tego nurtu użytkownik jest w centrum prac rozwojowych, a dotychczasowe „testy użytkownika” zastąpione zostały pojęciem „doświadczenia użytkownika” (customer experience). Wiele firm z branż nowych technologii buduje obecnie przewagi konkurencyjne na podstawie doświadczeń klienta w całym cyklu kontaktu z produktem lub usługą (service design) ${ }^{13}$. Od lat dziewięćdziesiątych ubiegłego stulecia można mówić o rozwoju projektowania zorientowanego na człowieka (human-centered-design), a podejście design thinking stało się swego rodzaju filozofią myślenia, stawiającą człowieka w centrum działań rozwojowych. Zyskało ono szczególną popularność w kontekście innowacji, wdrażania zmian organizacyjnych i rozwiązywania kompleksowych problemów (wicked problems) w kompleksowej rzeczywistości przedsiębiorstw ${ }^{14}$.

W ostatnich latach pojawiają się tezy, że design thinking może wspierać proces realizacji strategii, a w szczególności w obszarze strategii innowacji i pobudzania kreatywności organizacyjnej ${ }^{15}$. Tabela 1 precyzuje, w jakich sytuacjach design thinking jest rekomendowaną metodą realizacji celów strategicznych w odróżnieniu od tradycyjnego wdrażania strategii przez projekty.

Tabela 1. Zastosowanie design thinkingu do rozwiązywania problemów strategicznych

\begin{tabular}{|l|l|}
\hline \multicolumn{1}{|c|}{$\begin{array}{c}\text { Sytuacje, w których rekomendowane } \\
\text { są metody bazujące na design thinkingu }\end{array}$} & $\begin{array}{l}\text { Sytuacje, w których rekomendowane jest } \\
\text { uruchamianie projektów do realizacji strategii } \\
\text { (strategy by projects) }\end{array}$ \\
\hline $\begin{array}{l}\text { Rozwijanie nowych sposobów obsługi klienta } \\
\text { oraz oferty produktowej. }\end{array}$ & $\begin{array}{l}\text { Uruchamianie dużych projektów z wysokimi } \\
\text { oczekiwaniami dotyczącymi zwrotu } \\
\text { z inwestycji, możliwość zdefiniowania } \\
\text { w czasie i w ramach parametrów projektu. }\end{array}$ \\
\hline $\begin{array}{l}\text { Myślenie kreatywne, przezwyciężanie } \\
\text { myślenia ortodoksyjnego, koncentrującego } \\
\text { się na utrzymaniu status quo. }\end{array}$ & $\begin{array}{l}\text { Dokonywanie wyborów opartych } \\
\text { na „twardych” danych i podejmowanie } \\
\text { decyzji, które można uzasadnić biznesowo. }\end{array}$ \\
\hline $\begin{array}{l}\text { Pokonywanie problemu braku lub za małej } \\
\text { liczby pomystów biznesowych. }\end{array}$ & $\begin{array}{l}\text { Urynkowienie pomystów biznesowych } \\
\text { i uzyskanie efektów skali. }\end{array}$ \\
\hline \multicolumn{2}{|l}{} \\
\hline \multicolumn{2}{|l}{}
\end{tabular}

12 D.A. Norman, S.W. Draper, User centered system design. New Perspectives on Human-Computer Interaction, L. Erlbaum Associates Inc., Hillsdale 1986.

13 Należą do nich między innymi: Apple, Google, Amazon, Starbucks i inne: L. Kimbell, Designing for Service as One Way of Designing Services, „International Journal of Design” 2011, vol. 5(2), s. 41-52.

14 U. Johansson-Sköldberg, J. Woodilla, M. Çetinkaya, Design thinking: past, present and possible futures, "Creativity and Innovation Management” 2013, vol. 22(2), s. 121-146.

15 J. Kolko, Design Thinking comes of Age, „Harvard Business Review”, September 2015, s. 67-71. 


\begin{tabular}{|l|l|}
\hline \multicolumn{1}{|c|}{$\begin{array}{c}\text { Sytuacje, w których rekomendowane } \\
\text { są metody bazujące na design thinkingu }\end{array}$} & $\begin{array}{l}\text { Sytuacje, w których rekomendowane jest } \\
\text { uruchamianie projektów do realizacji strategii } \\
\text { (strategy by projects) }\end{array}$ \\
\hline $\begin{array}{l}\text { Odkrycie potrzeby klienta na bazie obserwacji } \\
\text { jego zachowań; eksplorowanie nowych } \\
\text { pomystów. }\end{array}$ & $\begin{array}{l}\text { Zrozumienie sposobu myślenia klienta } \\
\text { na temat przysztej oferty - zbieranie wymagań } \\
\text { tatwych do wyartykułowania i diagnozy. }\end{array}$ \\
\hline $\begin{array}{l}\text { Poprawienie doświadczenia klientów i innych } \\
\text { użytkowników z produktem, ustugą, marką } \\
\text { (customer experience). }\end{array}$ & $\begin{array}{l}\text { Utrzymanie lub dokonanie transformacji } \\
\text { catego biznesu, włączywszy model } \\
\text { przychodów, podejście do rynku, kanaty } \\
\text { i ekosystemy. }\end{array}$ \\
\hline $\begin{array}{l}\text { Wykreowanie pomystów do wdrożenia } \\
\text { w ramach predefiniowanej strategii. }\end{array}$ & $\begin{array}{l}\text { Priorytetyzacja istniejących inicjatyw } \\
\text { i decyzja, które wdraźá teraz, które } \\
\text { ignorować, a które uznać za model działania } \\
\text { w przyszłości. }\end{array}$ \\
\hline
\end{tabular}

Źródło: opracowanie własne na podstawie K. Das, Finding the Sweetspot between the Strategy and Design, Point of View, „Rotman Management Journal”, Fall 2014.

Verganti w swoich badaniach dochodzi do wniosku, że podejście design thinking zwiększa szansę przedsiębiorstw na wykreowanie nowych rynków i nowych znaczeń dla istniejących już produktów ${ }^{16}$. Stąd ta metoda pracy może stanowić istotne źródło budowania przewag konkurencyjnych.

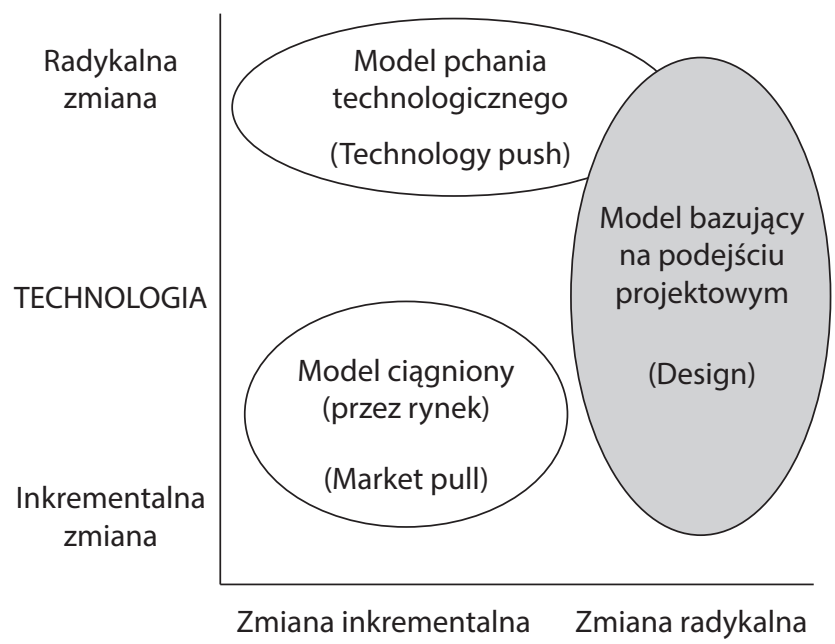

ZNACZENIE

Rysunek 1. Design w tworzeniu innowacji radykalnych (model Vergantiego)

Źródło: R. Verganti, Design, meanings, and radical innovation: A metamodel and a research agenda, „Journal of Product Innovation Management” 2008, vol. 25(5), s. 442.

16 R. Verganti, C. Dell'era, Design-driven innovation, Harvard Business Press, Boston 2009. 


\section{Zasady i proces pracy w metodach projektowych}

Jak wspominano na wstępie artykułu, w ramach tzw. podejść projektowych można wyróżnić różne odmiany metody. Przykładowo: wariację podejścia design thinking stanowi metoda design driven development (DDD) stosowana w branży rozwoju oprogramowania lub na przykład design sprint, które może być wykorzystane $\mathrm{w}$ projekcie eksploracyjnym projektowania innowacyjnego przedsięwzięcia typu start-up ${ }^{17}$. Niemniej, niezależnie od stosowanego wariantu metody, dla podejść projektowych można sformułować kilka wspólnych zasad ${ }^{18}$ :

- Obserwacja i zrozumienie: zrozumienie użytkownika i jego „ukrytych” potrzeb (latent needs) zakłada jego intensywną obserwację w realnych sytuacjach życia i pracy. Zanurzenie w świat klienta i empatyczne wczucie się w jego potrzeby pozwala na zrozumienie motywów działania oraz identyfikację potrzeb, których sam klient czy użytkownik nie jest świadomy, a w związku z tym trudno będzie mu je wyartykułować, na przykład w formie specyfikacji wymagań.

- Eksploracja i iteracja: w przeciwieństwie do podejść formalno-analitycznych podejście projektowe zakłada, że na wstępie projektu trudno jednoznacznie zdefiniować problem i cel przedsięwzięcia, a tym bardziej podać jednoznaczne rozwiązanie. Dopiero w procesie eksperymentowania i testowania rozwiązań, dla być może kilku różnie sformułowanych problemów, okazuje się, co powinno i może być zrobione. Proces taki nie jest linearny, krokowy, ale iteracyjny i może stanowić pętlę sprzężeń zwrotnych na różnych etapach projektu. W literaturze opisuje się go jako system nakładających się na siebie przestrzeni (system of overlapping spaces).

- Koncentracja na kliencie/użytkowniku: kryterium sukcesu w realizacji projektów jest rozwiązanie problemu, spełnienie potrzeb klienta lub użytkownika oraz poprawa doświadczeń, które ma on z produktem lub usługą. W związku z tym klient lub użytkownik angażowani są w pracę nad produktem od samego początku. W trakcie prac rozwojowych pozyskiwana jest często informacja zwrotna na bazie opracowanych artefaktów: prototypów i makiet produktu. Ponadto w procesie stosuje się wiele metod ilościowych i jakościowych pozwalających na walidację rozwiązania.

- Wizualizacja i prototypowanie: podejścia projektowe podkreślają znaczenie tworzenia fizycznych artefaktów, które pomogą testować produkt lub

17 R. Banfield, C.T. Lombardo, T. Wax, Design Sprint: A Practical Guidebook for Building Great Digital Products, O'Reilly Media Inc., Sebastopol 2015.

18 Ch. Gartner, R. Ludwig, Design-Thinking im Projektmanagement, „Zeitschrift fur Organization", April 2015, s. 260. 
rozwiązanie na wczesnym etapie powstawania. Dzięki temu użytkownik, potencjalny klient może dać wartościową informację zwrotną. Wizualizacje i prototypy wywołują bezpośrednie emocjonalne zaangażowanie i stanowią dobrą prognozę, w jaki sposób późniejsza usługa lub produkt będą postrzegane przez klienta/użytkownika.

- Ustrukturyzowana praca zespołowa: podejścia projektowe wykorzystują różnorodność zespołów i narzędzia pracy kreatywnej, na przykład różne odmiany burzy mózgów. Założeniem jest bazowanie na pomysłach innych i wykorzystanie mądrości grupowej w procesie definiowania i rozwiązywania problemów.

Design thinking koncentruje się na tzw. użyteczności (usability) rozwiązania. Dopiero na późniejszym etapie powstałe w ten sposób pomysły powinny zostać ocenione również pod względem wykonalności technologicznej oraz uzasadnienia biznesowego (rysunek 2). Te pomysły, które przejdą pozytywnie dwie kolejne oceny, mogę być brane pod uwagę w dalszym wdrożeniu i komercjalizacji.

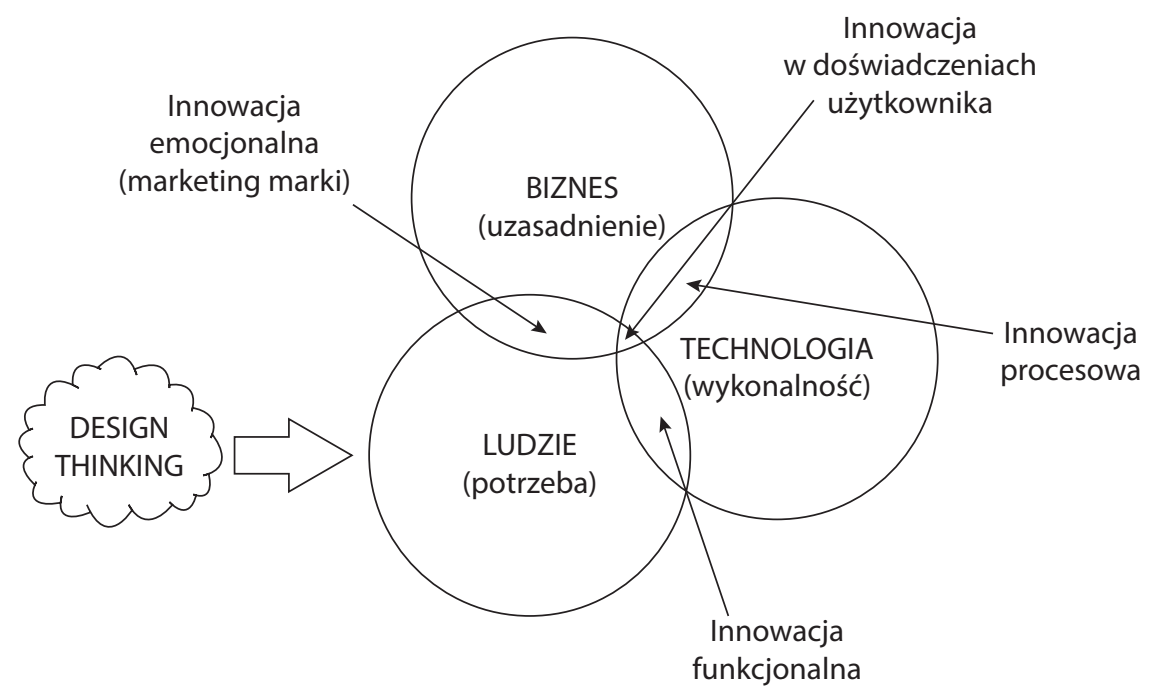

Rysunek 2. Elementy oceny pomystów w podejściu projektowym

Źródło: opracowanie własne na podstawie zasobów Ideo - https:// www.interaction-design.org (dostęp: 1.02.2020). 

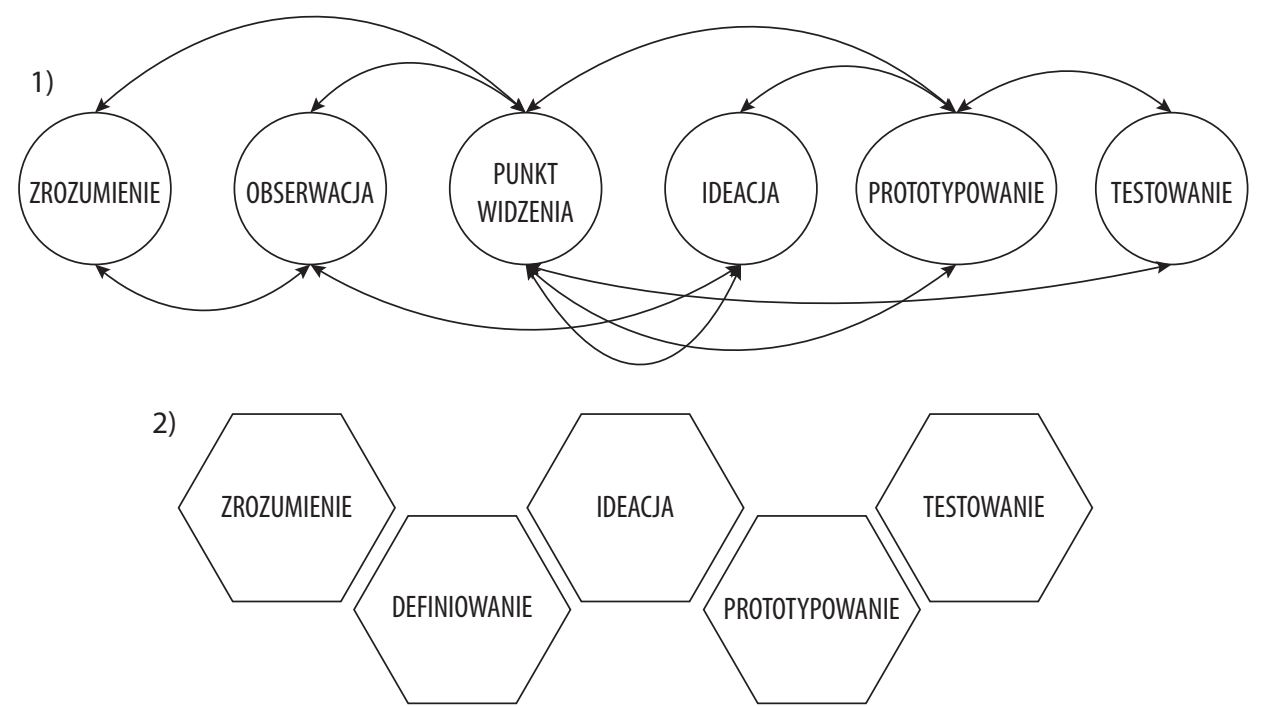

Rysunek 3. Modele Design Thinking Hasso Plattner Institute - warianty 6- i 5-krokowy

Źródto: An Introduction to Design Thinking Process Guide, Hasso

Plattner Institute of Design, Stanford 2010, s. 3.

Na rynku istnieje cała gama podejść projektowych ${ }^{19}$. W artykule naszkicowany będzie jedynie sposób postępowania rekomendowany w modelu instytutu Hasso Plattner w Poczdamie (rysunek 3). Podejście Hasso Plattner zostało opracowane głównie do celów edukacyjnych i obejmuje sześć (lub w niektórych opracowaniach pięć) kroków powiązanych pętlami zwrotnymi: 1) zrozumienie i 2) obserwację, 3) sformułowanie punktu widzenia na problem (point of view), 4) ideację, 5) prototypowanie, 6) testy. Na etapie zrozumienia pozyskiwane są informacje na temat danego wyzwania projektowego ze źródeł wtórnych oraz badań pierwotnych. Jednym z kluczowych elementów jest tu próba empatycznego „zanurzenia się” w świat klienta i użytkownika, mająca na celu dobre zdefiniowanie problemu. Drugi krok (obserwacja) często stanowi element fazy empatii i bazuje na badaniach jakościowych, które obejmują wywiady i techniki wspierające obserwację użytkownika w realnym środowisku. Rezultatem tych dwóch etapów jest pozyskanie wglądu w potrzeby użytkownika, a w szczególności zrozumienie motywów jego działania (insights). W kolejnym kroku przez opowiadanie historii użytkownika (persony) grupa projektowa dzieli się swoimi obserwacjami z pierwszych etapów i w ramach syntezy danych formułowany jest tzw. punkt widzenia na problem (point of view - POV) z perspektywy

19 Między innymi: model 3I firmy IDEO, model Hasso Plattner Institute, model British Design Council, podejście Service Design Thinking Model. 
użytkownika. Etap ideacji koncentruje się na generowaniu jak największej liczby pomysłów, które pomogą rozwiązać zdefiniowany problem, przy założeniu powstrzymania się od oceny wykonalności biznesowej. Pod koniec tej fazy liczba pomysłów jest zawężana do kilku najbardziej obiecujących i finalnie wybierane jest jedno rozwiązanie. Na etapie prototypowania powstają fizyczne artefakty ilustrujące sposób rozwiązania problemu, które są z kolei weryfikowane i sprawdzane na etapie testów. Pozyskiwane informacje zwrotne pozwalają ulepszyć rozwiązanie lub powrócić do poprzednich etapów, w przypadku gdy potrzebne jest na przykład przedefiniowanie sformułowanego poprzednio problemu.

\section{Sposoby rozumowania i uczenia się w podejściu projektowym}

W stosunku do klasycznych, analitycznych metod rozwiązywania problemów podejście projektowe ma dwie zalety związane z perspektywą kognitywną, a głównie tym, jak myślą i uczą się ludzie ${ }^{20}$. Po pierwsze, wykorzystuje różne sposoby rozumowania. Po drugie, akcentuje aspekty uczenia się w procesie rozwoju innowacyjnego rozwiązania. Jeśli chodzi o kwestię różnych stylów rozumowania, to tradycyjne metody, stosowane również w inicjowaniu projektu w tradycyjnych metodach zarządzania projektami, bazują głównie na myśleniu formalno-analitycznym (dedukcyjnym lub indukcyjnym). Polegają one na postawieniu problemu, ocenie opcji rozwiązania i wyborze najlepszej z nich. Podejścia projektowe, oprócz dochodzenia do rozwiązań drogą dedukcji i indukcji, angażują inny styl rozumowania, znany w literaturze jako myślenie abdukcyjne (abductive thinking). Pojęcie myślenia abdukcyjnego, rozwinięte przez filozofa Pierce’a, bazuje na założeniu, że żadna nowa idea nie może powstać przy użyciu rozumowania dedukcyjnego lub indukcyjnego stosującego dane z przeszłości ${ }^{21}$. Myślenie abdukcyjne w procesie kreatywnego rozwiązywania problemów pozwala na eksplorację alternatywnych rozwiązań, połączeń pomiędzy pozornie niepasującymi do siebie elementami. Wspiera je pozyskiwanie wglądu w problem (insights) oraz identyfikacja wzorców w zebranych danych. Rozumowanie abdukcyjne w połączeniu $\mathrm{z}$ intensywnymi badaniami oraz syntezą obserwacji jest esencją

20 S.B. Mahmoud-Jouini, Ch. Midler, P. Silberzahn, Contributions of design thinking to project management in an innovation context, „Project Management Journal” 2016, vol. 47(2), s. $144-156$.

21 R. Martin, The Design of Business. Why Design Thinking is the next Competitive Advantage, Harvard Business Press, Boston 2009, s. 29; L.M. Mayer, Design Thinking a View through the Lens of Practice, „OD Practicioners” 2015, vol. 47, no. 4, s. 44. 
podejść projektowych stosowanych w kreatywnym rozwiązywaniu problemów ${ }^{22}$. Ponadto w podejściu projektowym stosowane są naprzemiennie wzorce pracy polegające na kreowaniu dużej liczby możliwych opcji (myślenie dywergentne), po czym następuje faza zawężania opcji i wyboru (myślenie konwergentne). Naprzemienne stosowanie przez zespół projektowy różnych stylów myślenia wspiera kreatywność i poszukiwanie ciekawych pomysłów ${ }^{23}$.

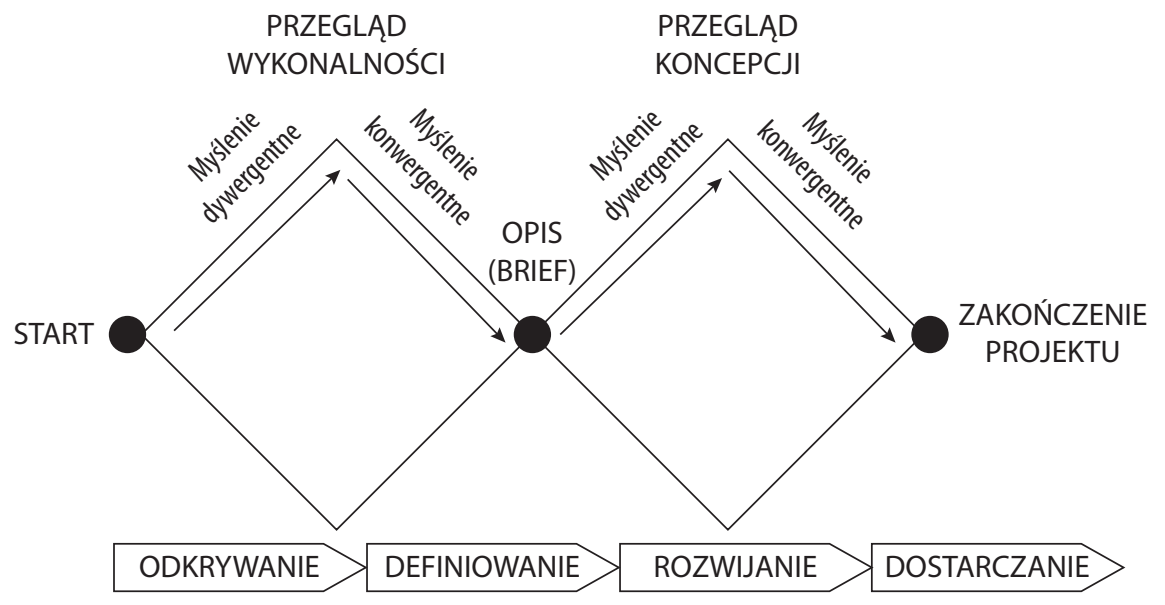

Rysunek 4. Myślenie dywergentne i konwergentne w procesie projektowym

Źródto: opracowanie własne na podstawie T. Brown, Change by design: how design thinking transforms organizations and inspires innovation, Harper Business, New York 2009.

Ponadto badacze adresują walory indywidualnego i zespołowego uczenia się przez wykorzystanie podejścia design thinking. W szczególności podkreślane jest umożliwienie uczenia się przez doświadczanie i refleksję 24 . Design thinking jest również użyteczny w procesie tzw. podwójnego poszerzania przestrzeni, które dotyczy zarówno istniejących koncepcji (concept), jak i istniejącej wiedzy (knowledge) (concept-knowledge theory). Tego rodzaju rozszerzanie istniejącej przestrzeni wiedzy ma szczególne zastosowanie na przykład w badaniach podstawowych lub kreowaniu radykalnych innowacji 25 .

22 J. Kolko, Abductive thinking and sensemaking: The drivers of design synthesis, „Design Issues" 2010, vol. 26(1), s. 20.

23 T. Brown, Change by design: how design thinking transforms organizations and inspires innovation, Harper Business, New York 2009.

24 K. Hölzle, H. Rhinow, The Dilemmas of Design Thinking in Innovation Projects, „Project Management Journal" 2019, vol. 50(4), s. 418-430.

25 S. Lenfle, P. Le Masson, B. Weil, When project management meets design theory: revisiting the Manhattan and Polaris projects to characterize 'radical innovation' and its managerial implications, „Creativity and Innovation Management” 2016, vol. 25(3), s. 378-395. 


\section{Narzędzia w podejściach projektowych}

Cenną zdobyczą podejść projektowych jest rozwinięcie szerokiego instrumentarium narzędzi i technik, które mogą wzbogacać pracę z przedsięwzięciami innowacyjnymi i projektami o charakterze eksploracji. Zostały one zaczerpnięte z wielu dziedzin wiedzy: sztuki, inżynierii, antropologii, psychologii, marketingu i innych. Tabela 2 zestawia wybrane narzędzia i techniki oraz możliwości ich zastosowania na poszczególnych etapach procesu projektowego.

Tabela 2. Wybrane narzędzia i techniki w procesie projektowym

\begin{tabular}{|c|c|}
\hline Zastosowanie & Opis narzędzi i technik \\
\hline $\begin{array}{l}\text { Empatia } \\
\text { i obserwacja }\end{array}$ & $\begin{array}{l}\text { Shadowing - zanurzenie się w życiu klienta przez bliską obserwację } \\
\text { oraz opracowywanie notatek. Pomaga zebrać potrzeby niewyartykuło- } \\
\text { wane i nieuświadomione przez klienta/użytkownika. } \\
\text { Service Safari - badacze wchodzą w realną sytuację i eksplorują włas- } \\
\text { ne dobre i zte doświadczenia z daną usługą. } \\
\text { Autodokumentacja (self-documentation) - użytkownik obserwuje } \\
\text { siebie według zarysowanego scenariusza oraz rejestruje te obserwacje } \\
\text { w dzienniku, za pomocą fotografii lub wideo. } \\
\text { Techniki mapowania - służą systematycznej organizacji informacji } \\
\text { oraz komunikowaniu ich za pomocą wizualizacji. Można tu wyróż- } \\
\text { nić proste diagramy, rysunki, slajdy. Są różne odmiany map: affinity } \\
\text { maps, empathy maps, expectation maps lub mapy procesowe służące } \\
\text { np. do opisu ścieżki doświadczeń klienta z produktem/usługą - jour- } \\
\text { ney maps. } \\
\text { Mapy myśli๋ - pomagają ustrukturyzować informacje wokół centralne- } \\
\text { go tematu oraz dodać słowa kluczowe kojarzące się z tematem. } \\
\text { Persona - to narzędzie bazujące na fikcyjnej postaci, które powstaje } \\
\text { na podstawie zebranych o użytkowniku/kliencie informacji. Persona } \\
\text { pomaga zwizualizować tzw. archetyp klienta docelowego. Często } \\
\text { stosowana jest w połączeniu z techniką mapy empatii, która pomaga } \\
\text { zorganizować informacje o personie pozyskane na etapie wywiadów. }\end{array}$ \\
\hline $\begin{array}{l}\text { Generowanie idei } \\
\text { (ideacja) }\end{array}$ & $\begin{array}{l}\text { Burza mózgów - jej celem jest wygenerowanie w krótkim czasie jak } \\
\text { największej liczby pomystów, w których emocje i intuicja mają większe } \\
\text { znaczenie niż myślenie racjonalne i analityczne. Z uwagi na ograni- } \\
\text { czenia tradycyjnej metody burzy mózgów, wykorzystującej werbalną } \\
\text { formę komunikacji, stosuje się często inne odmiany burzy mózgów. } \\
\text { Brainwriting - wariant burzy mózgów pozwalający na pracę cichą i opi- } \\
\text { sanie pomysłów na karteczkach post-it. W kolejnym etapie pomysty } \\
\text { są porządkowane i kategoryzowane. } \\
\text { Brainsketching - techniki rysowania są odmianą burzy mózgów i mogą } \\
\text { pomóc w wizualizacji idei za pomocą prostych rysunków. } \\
\text { Techniki wizualnej i znaczeniowej konfrontacji (np. Visual Sinectics, } \\
\text { Forced Relationship, Semantic Intuition) - utatwiają myślenie integrują- } \\
\text { ce odległe od siebie idee i koncepcje, a także pozwalają na kombinację } \\
\text { abstrakcyjnych idei z rzeczywistymi artefaktami. Wspierają kreatywne } \\
\text { rozwiązywanie problemów. }\end{array}$ \\
\hline
\end{tabular}


Tabela 2. (cd.)

\begin{tabular}{|l|l|}
\hline \multicolumn{1}{|c|}{ Zastosowanie } & \multicolumn{1}{c|}{ Opis narzędzi i technik } \\
\hline Prototypowanie/ & $\begin{array}{l}\text { Storyboarding - technika obejmująca zestawienie wizualizacji (rysun- } \\
\text { téw, fotografii, slajdów PPT, karteczek post-it), która wspiera odzwier- } \\
\text { ciedlenie procesu, usługi lub wydarzenia. Nadaje się do ilustrowania } \\
\text { etapów w interakcji człowieka z produktem lub ustugą, promuje dialog } \\
\text { między użytkownikiem a projektantem. } \\
\text { Storytelling - technika używana w procesie projektowym w celu } \\
\text { zakomunikowania idei/pomysłu/rozwiązania w kontekście problemu } \\
\text { użytkownika/klienta i jego rozwiązania. Historie mają mieć charakter } \\
\text { ilustracyjny, symboliczny i tatwy do zapamiętania. } \\
\text { Role Playing - technika, która odzwierciedla realną konfrontację klien- } \\
\text { ta z produktem. Takie wydarzenie testowe jest filmowane, aby móc } \\
\text { wyciągnąć wnioski do dalszych usprawnień. } \\
\text { Makiety (mock-ups) - stużą do szybkiego prototypowania i przete- } \\
\text { stowania lub zademonstrowania nowego produktu. Często tączone } \\
\text { są z narzędziami Storyboard lub Role Playing, aby w sposób wizualny } \\
\text { przedstawić, jak użytkownik korzysta z produktu lub usługi. }\end{array}$ \\
\hline
\end{tabular}

* T. Buzan, B. Buzan, The mind map book: Radiant Thinking - Major

Evolution in Human Thought, BBC Books, London 1993.

Źródło: opracowanie własne na podstawie K. Tschimmel, Design Thinking as an effective Toolkit for Innovation, [w:] ISPIM Conference Proceedings, The International Society for Professional Innovation Management (ISPIM), January 2012, s. 6.

\section{Zakończenie}

Pytanie badawcze artykułu brzmiało: „Jakie są możliwości i ograniczenia wykorzystania metod projektowych w projektach o charakterze eksploracyjnym?". Krytyczna analiza literatury przedmiotu i podejścia design thinking pozwala na sformułowanie tezy, że integrowanie tej metody i proponowanych narzędzi w ramach cyklu życia projektu może istotnie wspierać zarządzanie projektami, a w szczególności pracę z projektami o charakterze eksploracji. Design thinking ma tę zaletę, że w jasny sposób przedstawia postępowanie w kreatywnym procesie poszukiwania rozwiązań, jak również czyni go bardziej zrozumiałym i dostępnym do zastosowania w organizacjach oraz biznesie. Stąd podejścia projektowe mogą wesprzeć zarządzanie projektami, w szczególności w obszarze poprzedzającym etap inicjowania projektów, na przykład w analizie istniejących problemów. Dzięki eksploracji i uczeniu się wzrastają szanse na wyłonienie się właściwego pomysłu lub odkrycie nowego potencjału rynkowego ${ }^{26}$. Design thinking dobrze spisuje się w rozwiązywaniu problemów, które nie są łatwe do opisania, a także nadaje się do wdrażania

26 R. Hirschfeld, B. Steinert, J. Lincke, Agile software development in virtual collaboration environments, [w:] Design Thinking, Springer, Berlin-Heidelberg 2011, s. 197-218; S.B. Mahmoud-Jouini, Ch. Midler, P. Silberzahn, Contributions of design thinking... 
inkrementalnych usprawnień dla poprawy doświadczeń klienta z produktem lub usługą. Siłą design thinkingu jest skoncentrowanie na użytkowniku/kliencie, a w szczególności na jego ukrytych potrzebach. Stąd metoda ta wspiera pracę z kluczowymi interesariuszami projektu. Ponadto podejście może wspomóc organizację we wdrażaniu strategii innowacji lub ustanawiania projektów w obszarze rozwoju innowacyjnych przedsięwzięć z dużym udziałem technologii informatycznych 27 . Design thinking może uzupełniać tradycyjny cykl pracy projektowej o różnorodne narzędzia i techniki pracy kreatywnej, a proces sprzężeń zwrotnych pomaga dotrzeć do przyczyn źródłowych problemów lub problemy te wręcz redefiniować. Design thinking może być płynnie zintegrowany ze zwinnym podejściem do wytwarzania produktów, na przykład przez zaangażowanie eksperta ds. doświadczeń klienta do zespołu deweloperskiego. Siłą podejść projektowych jest wsparcie procesów kognitywnych, takich jak wykorzystanie różnorodnych stylów rozumowania, jak również uczenia się poszczególnych pracowników i całych zespołów. Podsumowując, zintegrowanie perspektywy design thinking (bazującej na założeniach współpracy, optymizmu, kreatywności) ze światem uporządkowanej, racjonalnej logiki zarządzania projektami ma potencjał stworzenia zestawu praktyk pozwalających na skuteczne wsparcie procesów inicjowania oraz wdrażania zmian i innowacji w organizacjach ${ }^{28}$. Tabela 3 zestawia możliwości zastosowania design thinkingu w ramach obszarów zarządzania projektami.

Tabela 3. Zastosowanie design thinkingu w kontekście zarządzania projektami

\begin{tabular}{|l|l|}
\hline $\begin{array}{c}\text { Wymiar zarządzania } \\
\text { projektami }\end{array}$ & \multicolumn{1}{c|}{ Zastosowanie design thinkingu } \\
\hline Cel projektu & $\begin{array}{l}\text { - Projekty o trudnym do zdefiniowania zakresie, a w związku z tym } \\
\text { również innych parametrów projektu. } \\
\text { - Eksploracja rozwiązań i szans. }\end{array}$ \\
\hline Cykl życia projektu & $\begin{array}{l}\text { - Wsparcie analizy przed projektem, a także etapu inicjowania } \\
\text { i definiowania projektu. }\end{array}$ \\
\hline $\begin{array}{l}\text { - Wsparcie w obszarze rozproszonego miejsca powstawania } \\
\text { innowacji (fuzzy front end) oraz współtworzenia innowacji } \\
\text { z użytkownikiem, klientem lub dostawcą. }\end{array}$ \\
\hline Parametry sukcesu \\
projektu
\end{tabular}

27 R. Unger, C. Chandler, A Project Guide to UX Design: For user experience designers in the field or in the making, New Riders, Berkeley 2012; J. Levy, Strategia UX. Jak tworzyć innowacyjne produkty cyfrowe, które spotkajq się z uznaniem rynku, Wydawnictwo Helion, Gliwice 2016.

28 M. Bernstein, M. Linsky, Leading Change through Adaptive Design, „Stanford Social Innovation Review" 2016, s. 54. 
Tabela 3. (cd.)

\begin{tabular}{|l|l|}
\hline $\begin{array}{c}\text { Wymiar zarządzania } \\
\text { projektami }\end{array}$ & \multicolumn{1}{c|}{ Zastosowanie design thinkingu } \\
\hline $\begin{array}{l}\text { Obszary zarządzania } \\
\text { projektem }\end{array}$ & - Interesariusze: Wsparcie procesu zarządzania kluczowymi \\
& użytkownikami/klientami. \\
& - Ryzyko: Wsparcie dla strategii ograniczania ryzyka związanego \\
& z rozwojem nowych produktów i usług przez wczesne \\
& prototypowanie i testowanie. \\
& - Zespół: Wykorzystanie efektów różnorodności członków zespołu \\
projektowego/uczenia się i wykorzystania różnych stylów myślenia; \\
wykorzystanie narzędzi pracy kreatywnej. \\
- Komunikacja: Wykorzystanie bezpośrednich kanatów komunikacji, \\
praca z wizualizacją i fizycznymi artefaktami w celu szybkiej \\
walidacji pomysłu.
\end{tabular}

Źródto: opracowanie wtasne.

Z drugiej strony w literaturze pojawiają się również liczne głosy krytyczne dotyczące design thinkingu, wskazujące na ograniczenia dla wdrożenia podejścia w praktyce ${ }^{29}$. Wskazywane jest niebezpieczeństwo zbytniego upraszczania i błędnego stosowania, co powoduje trywializację metody i narastanie niechęci do jej wykorzystania. Częste stosowanie może powodować efekt znudzenia metodą. Zagrożeniem jest niedostosowanie metody do typu problemów lub typu projektów. Pomysły rodzą się w praktyce z wielu źródeł, na przykład w wyniku długoterminowych prac badawczo-rozwojowych, jak również współdziałania całego ekosystemu interesariuszy rynkowych. Stąd metoda ta nie może być traktowana jako panaceum na wszelkie bolączki. Założenia design thinkingu są dosyć wymagające i bazują na gotowości interesariuszy do współpracy oraz otwartości na eksperymentowanie - w praktyce często istnieją różnice celów oraz rozbieżności agend wśród uczestników i decydentów w procesie ${ }^{30}$. Proces „wykluwania się" pomysłu w design thinkingu może długo trwać i generować trudności, szczególnie kiedy projekt jest pod presją czasu lub gdy czas jest krytycznym czynnikiem sukcesu. Podnoszony jest również problem pomiaru korzyści i dokumentowania zwrotu $\mathrm{z}$ inwestycji we wdrożenie design thinkingu, które to $\mathrm{z}$ założenia koncentruje się na użyteczności, a nie na opłacalności biznesowej. Niektórzy autorzy podkreślają, że wdrożenie tego podejścia wymaga transformacji organizacji i jej kultury (wartości, norm, zachowań). Orientacja na design powinna stać się „drugą naturą” organizacji i współgrać z jej kulturą i systemem motywacyjnym. Stosowanie podejścia prowadzi nieuchronnie do kwestionowania status-quo w organizacji i w związku

29 L. Carlgren, M. Elmquist, I. Rauth, The challenges of using design thinking in industry - experiences from five large firms, „Creativity and Innovation Management” 2016, vol. 25(3), s. 344-362.

30 Ch. Gartner, R. Ludwig, Design-Thinking..., s. 260. 
z tym może napotkać opór ${ }^{31}$. Ponadto wymaga dużej tolerancji dla porażki, gdyż otwartość na popełnianie błędów jest nieodłącznym składnikiem procesu projektowego ${ }^{32}$.

Podsumowując, artykuł omawia możliwości i wyzwania zastosowania design thinkingu w zarządzaniu projektami. Ograniczeniem badania jest jego przeglądowy charakter, bazujący na krytycznej ocenie literatury przedmiotu oraz analizie podejścia design thinking Hasso Plattner Institute w kontekście zarządzania projektami. Stąd zebrane refleksje mogą być postrzegane jedynie jako punkt wyjścia do dalszych badań. Z uwagi na małą ilość dostępnej obecnie literatury istnieje szerokie pole do badań - zarówno jakościowych, jak i ilościowych. Przykładowo: ciekawy, jeśli chodzi o dalsze badania, jest obszar integrowania podejścia projektowego z metodami pracy zwinnej (np. Scrum). Kolejnym ciekawym obszarem jest zbadanie, jakie warunki muszą być spełnione w organizacji, aby potencjał design thinkingu mógł być w pełni wykorzystany. Kolejne interesujące pytanie badawcze dotyczy sposobu wykorzystania metod bazujących na designie na poziomie zarządzania portfelem projektów, a w szczególności w powiązaniu ze strategią otwartych innowacji. Ponadto zajmujące byłoby badanie, co w praktyce decyduje o sukcesie rynkowym inicjatyw, które są realizowane jako wynik procesu design thinkingu.

\section{Bibliografia}

An Introduction to Design Thinking Process Guide, Hasso Plattner Institute of Design, Stanford 2010.

Banfield R., Lombardo C.T., Wax T, Design Sprint: A Practical Guidebook for Building Great Digital Products, O’Reilly Media Inc., Sebastopol 2015.

Bernstein M., Linsky M., Leading Change through Adaptive Design, „Stanford Social Innovation Review" 2016, s. 49-54.

Brown T., Change by design: how design thinking transforms organizations and inspires innovation, Harper Business, New York 2009.

Buchanan R., Wicked problems in design thinking, „Design Issues” 1992, vol. 8(2), s. 5-21.

Buzan T., Buzan B., The mind map book: Radiant Thinking - Major Evolution in Human Thought, BBC Books, London 1993.

Carlgren L., Elmquist M., Rauth I., The challenges of using design thinking in industry-experiences from five large firms, „Creativity and Innovation Management” 2016, vol. 25(3), s. 344-362.

Das K., Finding the Sweetspot between the Strategy and Design, Point of View, „Rotman Management Journal", Fall 2014.

Gartner Ch., Ludwig R., Design-Thinking im Projektmanagement, „Zeitschrift fur Organization”, April 2015, s. 255-261.

31 M. Bernstein, M. Linsky, Leading Change....

32 J. Kolko, Design Thinking... 
Hirschfeld R., Steinert B., Lincke J., Agile software development in virtual collaboration environments, [w:] Design Thinking, Springer, Berlin-Heidelberg 2011, s. 197-218.

Hobday M., Boddington A., Grantham A., An innovation perspective on design: Part 2, „Design Issues" 2012, vol. 28(1), s. 18-29.

Hölzle K., Rhinow H., The Dilemmas of Design Thinking in Innovation Projects, „Project Management Journal" 2019, vol. 50(4), s. 418-430.

https://www.interaction-design.org (dostęp: 1.02.2020).

Ignatius A., Design as strategy, „Harvard Business Review” 2015, no. 12.

Johansson-Sköldberg U., Woodilla J., Çetinkaya M., Design thinking: past, present and possible futures, „Creativity and Innovation Management” 2013, vol. 22(2), s. 121-146.

Kimbell L., Designing for Service as One Way of Designing Services, „International Journal of Design" 2011, vol. 5(2), s. 41-52.

Koen P., Ajamian G., Burkart R., Clamen A., Davidson J., D’Amore R., Karol R., Providing clarity and a common language to the "fuzzy front end", „Research-Technology Management" 2001, vol. 44(2), s. 46-55.

Kolko J., Abductive thinking and sensemaking: The drivers of design synthesis, „Design Issues” 2010, vol. 26(1), s. 15-28.

Kolko J., Design Thinking comes of Age, „Harvard Business Review”, September 2015, s. 67-71.

Lenfle S., Floating in space? On the strangeness of exploratory projects, „Project Management Journal" 2016, vol. 47(2), s. 47-61.

Lenfle S., Toward a genealogy of project management: Sidewinder and the management of exploratory projects, „International Journal of Project Management” 2014, vol. 32(6), s. 921-931.

Lenfle S., Loch C., Lost roots: How project management came to emphasize control over flexibility and novelty, „California Management Review” 2010, vol. 53(1), s. 32-55.

Lenfle S., Le Masson P., Weil B., When project management meets design theory: revisiting the Manhattan and Polaris projects to characterize 'radical innovation' and its managerial implications, „Creativity and Innovation Management” 2016, vol. 25(3), s. 378-395.

Levy J., Strategia UX. Jak tworzyć innowacyjne produkty cyfrowe, które spotkają się z uznaniem rynku, Wydawnictwo Helion, Gliwice 2016.

Mahmoud-Jouini S.B., Midler Ch., Silberzahn P., Contributions of design thinking to project management in an innovation context, „Project Management Journal” 2016, vol. 47(2), s. 144-156.

Maniak R., Midler C., Shifting from co-development to co-innovation, „International Journal of Automotive Technology and Management" 2008, vol. 8(4), s. 449-468.

Martin R., The Design of Business. Why Design Thinking is the next Competitive Advantage, Harvard Business Press, Boston 2009.

Mayer L.M., Design Thinking a View through the Lens of Practice, „OD Practitioners” 2015, vol. 47, no. 4 , s. $42-47$.

Midler Ch., Silberzahn P., Creating Products in the Absence of Markets: A Robust Design Approach, „Journal of Manufacturing Technology Management” 2008, vol. 19(3), s. 407-420.

Nightingale P., Brady T., Projects, paradigms and predictability, [w:] G. Cattani, S. Ferriani, L. Frederiksen, F. Täube (red.), Project-based organizing and strategic management, Emerald Group Publishing, Bingley 2011, s. 83-112.

Norman D.A., Draper S.W., User centered system design. New Perspectives on Human-Computer Interaction, L. Erlbaum Associates Inc., Hillsdale 1986.

Ritzer G., Jurgenson N., Production, consumption, prosumption: The nature of capitalism in the age of the digital 'prosumer', „Journal of Consumer Culture” 2010, vol. 10(1), s. 13-36.

Saebi T., Foss N.J., Business models for open innovation: Matching heterogeneous open innovation strategies with business model dimensions, „European Management Journal” 2015, vol. 33(3), s. 201-213. 
Shenhar A., Dvir D., Reinventing project management, Harvard Business School Press, Boston 2007.

Tschimmel K., Design Thinking as an effective Toolkit for Innovation, [w:] ISPIM Conference Proceeding, The International Society for Professional Innovation Management (ISPIM), January 2012.

Unger R., Chandler C., A Project Guide to UX Design: For user experience designers in the field or in the making, New Riders, Berkeley 2012.

Verganti R., Design, meanings, and radical innovation: A metamodel and a research agenda, „Journal of Product Innovation Management" 2008, vol. 25(5), s. 436-456.

Verganti R., Dell'era C., Design-driven innovation, Harvard Business Press, Boston 2009.

\section{Streszczenie}

Artykuł omawia możliwości zastosowania podejścia design thinking w zarządzaniu projektami. Podejście to stało się w ostatnich dekadach popularne zarówno w praktyce, jak i w literaturze z zakresu nauk o zarządzaniu, w szczególności zaś w kontekście wspierania innowacji, angażowania użytkownika lub klienta w proces rozwoju produktu i twórczego rozwiązywania kompleksowych problemów. W ramach dyscypliny zarządzania projektami pojawiło się kilka badań dotyczących możliwości zastosowania design thinkingu, szczególnie w projektach o charakterze eksploracyjnym. Niemniej istnieje luka badawcza dotycząca możliwości integracji instrumentarium design thinkingu w działalności projektowej przedsiębiorstw. Na podstawie przeglądu literatury oraz analizy metody design thinking Hasso Plattner Institute autorka analizuje możliwości i ograniczenia zastosowania tej metody w realizacji projektów, a także proponuje obszary przyszłych badań.

Słowa kluczowe: zarządzanie projektami, design thinking, inicjowanie projektu, projekty eksploracyjne 


\section{Design thinking in project management - assessment of application possibility}

\section{Abstract}

The article discusses the possibilities of using the design thinking approach in project management. This approach has become popular in recent decades both in practice and in literature in the field of management sciences. In particular, in the context of innovation management, engaging the user or customer in the product development process and creative approaches to solving complex problems. Several studies have emerged regarding the possibilities and advantages of the application of design thinking in project management. This has been especially discussed in the context of exploratory projects. Nevertheless, there is still a research gap regarding how design thinking practices can be integrated into project-based activities of an enterprise. Based on a comprehensive literature review and analysis of the design thinking approach proposed by Hasso Plattner Institute, the author analyzes the advantages and limitations for the application of the method in projects and also proposes areas for future research.

Keywords: project management, design thinking, project initiation, exploratory projects 